\title{
Chernobyl - Experience and Perspectives of International Cooperation and Environmental Protection
}

\author{
GiANFRANCO TAMBURELLi* \\ Tetiana Olexandrivna Kovalenko*
}

\begin{abstract}
The article analyses various stages of the subsequent development of the international cooperation and of Ukrainian legislation aimed at facing the consequences of the explosion at Chernobyl nuclear power plant, on April 26, 1986. It is aimed to assess the impact of Chernobyl accident on law and policies in the field of environmental protection. The reaction to the Chernobyl accident gave in fact a boost to the evolution of international treaty law in various sectors (nuclear safety, emergency preparedness and response, environmental law) and, according to the Authors, contributed to the assertion in general international law of the right to environmental information.

More than a thousand legal acts have been adopted in the Ukraine aimed at determining the safe management of the territories affected by Chernobyl accident. Notwithstanding the resulting nuclear contamination from Chernobyl accident still is a priority environmental problem. In this context, the Authors highlight the exceptional interest of the prospect opened by the Presidential Decrees of 2018 and 2019 on the rehabilitation of the territories affected by radioactive contamination. They represent a further important step towards the effective establishment of a biosphere reserve, in the perspective of the creation of a transboundary protected area with Belarus.

Keywords: Chernobyl accident, international law, nuclear energy, environmental law, Chernobyl Radiation and Ecological Biosphere Reserve.
\end{abstract}

\section{INTRODUCTION}

The explosion at the Chernobyl nuclear power plant, on April 26, 1986, was a planetary scale disaster and still has significant negative consequences, in particular for Belarus, in the Russian Federation and in Ukraine. The Japanese disaster in Fukushima Daiichiin in 2011 also reached 7, the same maximum level of classification on the international 'Ines' scale, ${ }^{1}$ but experts still consider the incident in Chernobyl (around $100 \mathrm{Km}$ from Kyiv) to be the most serious in history for the extent of leakage of radioactive material and effects on health and the environment. ${ }^{2}$

The explosion dispersed radioactive material over 100000 square kilometers of territory. The authorities sealed off a 30-kilometer exclusion zone around the reactor and

* Senior Legal Expert at the Institute for International Legal Studies of the National Research Council of Italy, Professor at Taras Shevchenko National University of Kyiv (Ukraine).

** Professor of Department of Land and Agrarian Law, Faculty of Law, Taras Shevchenko National University of Kyiv, Ukraine.

1 The International Nuclear and Radiological Event Scale (INES) is a tool for communicating the safety significance of nuclear and radiological events to the public (cf. https://www.iaea.org/ resources/databases/international-nuclear-and-radiological-event-scale). The third most serious nuclear accident ever recorded, behind Fukushima Daiichiand Chernobyl, is that of Kyshtym, which took place on September 29, 1957, at Mayak, a plutonium production site in Russia, and was rated at INES 6 level. Numerous nuclear accidents happened worldwide before and after Chernobyl. Among the most recent and most serious, occurred in EU Member States, those occurred in 2006 in Fleurus, Belgium (Ines level 4), and Forsmark, Sweden (Ines level 2); in 2005 in Sellafield, UK (Ines level 3); in 2003 in Paks, Hungary (Ines level 3). With regard to Paks, we might note that on May 4, 2009, another event was rated as Ines level 2.

2 Sangermano (2017). 
declared this area unsafe for human life for 20000 years. In Ukraine, the release of radioactive materials from the destroyed fourth block contaminated over 53500 thousand square kilometers of the territory. ${ }^{3}$ About 330 thousand people were evacuated from the explosion zone, including all 45 thousand inhabitants of the city of Pripyat. ${ }^{4}$

At that time, nuclear energy law consisted of a few international conventions and a number of technical recommendations. ${ }^{5}$ The Paris Convention on Third Party Liability in the Field of Nuclear Energy of July 29, 1960 (entered into force April 1, 1968) ${ }^{6}$ and the Vienna Convention on Civil Liability for Nuclear Damage of May 23, 1963 (entered into force November 12, 1977), ${ }^{7}$ containing rules on liability and compensation for nuclear damage, had been ratified by only a few States.

Thirty-three years later, it seems interesting and current for an analysis of the various stages of the subsequent development of the international cooperation and of Ukrainian legislation aimed at facing the consequences of the event. This analysis will be mainly aimed to assess the impact of the Chernobyl accident on law and policies in the field of environmental protection.

In this regard, first of all, it should be highlighted the delay of public authorities in spreading of information and the strong reaction of the international community. No report was in fact released until the third day after the explosion. The alarm was launched by Forsmark, Sweden's second largest nuclear power plant, soon after the detection of high levels of radiation, the analysis of a map of areas where this phenomenon occurred and of the wind direction, which allowed the determination that a nuclear accident had occurred somewhere in the Soviet Union. ${ }^{8}$

${ }^{3}$ More than 3 million people were affected by the consequences of the accident, including about 1 million children. Cf. <https://ua.112.ua/mnenie/pohliad-na-chornobylsku-katastrofu-v-tsyfrakh307705.html >accessed 14 February 2019.

${ }^{4}$ Pripyat was built in the early 1970s to house the workers and builders of the Chernobyl nuclear power plant with their families. Located in northern Ukraine, near the Belarusian border, about $3 \mathrm{~km}$ from the NPP, it was abandoned following the disaster.

${ }^{5}$ Cf. Arangio-Ruiz (1962).

6 The Paris Convention provides for compensation for injury to, or loss of life of any person, and for damage to, or loss of any property caused by a nuclear accident. On January 31, 1963, the Brussels Convention Supplementary to the Paris Convention on Third Party Liability in the Field of Nuclear Energy was adopted to provide additional funds to compensate damage as a result of a nuclear incident (entered into force on December 4, 1974). It stipulates that public funds are to be provided for this purpose, not only by the state where the liable operator's nuclear installation is located, but also by contributions from all parties to the Supplementary Convention.

7 The Vienna Convention on Civil Liability aims at harmonizing the national law of the contracting parties by establishing some minimum standards to provide financial protection against damage resulting from certain peaceful uses of nuclear energy. The legal regime provided for in the Convention is based on the following general principles: exclusive 'absolute' or 'strict' liability of the operator of the nuclear installation concerned; obligation for the operator to cover liability through insurance or other financial security; exclusive jurisdictional competence of the courts of the contracting party in whose territory the incident occurs; recognition and enforcement of final judgments rendered by the competent court in all contracting parties.

8 The Soviet authorities were conducting emergency fire fighting and clean-up operations, but television and radio channels were largely silent; the first reports about the explosion of the Chernobyl reactor were made by Swedish Radio, and Ukrainian Radio Svoboda. Cf. $<$ https://www.radiosvoboda. org/a/27707045.html >accessed 2 February 2019. 
A few months later, on September 26, 1986, in the framework of the International Atomic Energy Agency (IAEA), the Convention on Early Notification of a Nuclear Accident (in force, since October 27, 1986) ${ }^{9}$ and the Convention on Assistance in the Case of a Nuclear Accident or Radiological Emergency (in force since February 26, 1987) ${ }^{10}$ were signed. ${ }^{11}$ These Conventions certainly contributed, as will analyzed in more detail, to the progressive assertion in international law of the right to environmental information. ${ }^{12}$

It seems opportune also to note that no country could bring a valid claim seeking compensation against the USSR for Chernobyl because the USSR was not party to the above-mentioned Paris and Vienna Convention and the jurisdiction of the International Court of Justice (ICJ) is consent-based. ${ }^{13}$

To extend the application of the treaty principles on liability for damage, on September 21, 1988, on initiative of the IAEA and the OECD (Organization for Economic Co-operation and Development), a Joint Protocol relating to the Application of the Vienna Convention on

9 The Convention on Early Notification of a Nuclear Accident establishes a notification system for nuclear accidents from which a release of radioactive material occurs or is likely to occur and which has resulted or may result in an international transboundary release that could be of radiological safety significance for another State(Article 1, Scope of application). It requires States to report the accident's time, location, nature, and other data essential for assessing the situation (Article 2, Notification and information).

The three countries most affected by the Chernobyl accident (the Belarusian SSR, the Ukrainian SSR, and the USSR) promptly ratified the Convention, which entered into force in their national legal systems on February 26, 1987. On December 26, 1991 the Russian Federation notified that it would have continued the participation of the USSR in all conventions, agreements and international legal instruments concluded within the IAEA framework or under its aegis is continued by the Russian Federation.

10 The Convention on Assistance in the Case of a Nuclear Accident or Radiological Emergency sets out an international framework for co-operation among States Parties and with the IAEA to facilitate prompt assistance and support in the event of nuclear accidents or radiological emergenciesto minimize its consequences and to protect life, property and the environment from the effects of radioactive releases (Article 1, General provisions). If a State Party needs assistance, whether or not the accident or emergency originates within its territory, jurisdiction or control, it may call for such assistance from any other State Party. In case of a request, each State Party decides whether it can render the requested assistance as well as its scope and terms (Article 2, Provision of assistance).

The Belarusian SSR and the Ukrainian SSR ratified the Convention on January 26, 1987 (it entered in force in the two countries on February 26, 1987), the USSR ratified on December 23, 1986 (it entered in force on January 24, 1987).

11 It is worth to note that the Belarusian SSR, the Ukrainian SSR and the USSR ratified both the Conventions, affirming however, not considering themselves bound by the provisions of Article 11, paragraph 2 of the Convention on Early Notification and Article 13, paragraph 2 of the Convention on Assistance, which envisage the possibility of submitting a dispute between States Parties to arbitration or referring it to the ICJ at the request of any party. Ukraine stated that 'for submission of any international dispute to arbitration or referral to the ICJ the agreement of all parties in each individual case is necessary.'

12 The right to environmental information, and the existence of certain information obligations, are affirmed now in relation to the general duty of cooperation in the prevention and control of pollution, now in relation to the principle of the responsibility for environmental damage. Cf. Gaja (1986), 828.

13 The USSR failed to promptly notify its neighbors the occurrence of the accident. Cf. Mohit (2014). 
Third Party Liability in the Field of Nuclear Energy and the Paris Convention on Civil Liability for Nuclear Damage was adopted (in force since April 27, 1992). ${ }^{14}$ In this field, however, as will further considered, the evolution of international law has been modest.

\section{THE FIRST PHASE OF THE INTERNATIONAL COOPERATION}

During the first four years, the Soviet authorities dealt with the consequences of the explosion at a national level. Construction of a concrete sarcophagus covering the destroyed Unit 4 was started in May and completed in November 1986. Uncertainties about the actual condition of the sarcophagus began soon to emerge.

In April 1990, the Supreme Soviet, together with the Councils of Ministers of the Soviet Socialist Republics (SSRs) of Belarus and Ukraine, appealed to foreign governments, to international organizations and to worldwide public opinion for extensive international cooperation. On July 6, the three countries sent a letter to the UN Secretary General, recognizing that, notwithstanding the enormous efforts to deal with the effects of the accident at Chernobyl NPP and despite the considerable financial, material and technical resources committed, a reliable system for ensuring the safety of the people affected by radiation was still not in force. ${ }^{15}$

As a result, on December 21, 1990, the UN General Assembly adopted Resolution no. $45 / 190$ on Strengthening of international cooperation and coordination of efforts to study, mitigate and minimize the consequences of the Chernobyl disaster, which entrusted one of the under-Secretary-General with the task of coordinating the Chernobyl co-operation and called for the formation of an Inter-Agency Task Force. ${ }^{16}$ A Plan of international cooperation was prepared with the following priority areas identified: health, resettlement, economic rehabilitation of affected areas, socio-psychological rehabilitation of affected people, food and agricultural monitoring, environmental rehabilitation of the environment.

In the first months of 1991, various legislative acts regulating the responsibility of the government for the damage inflicted to the citizens as a result of the activities of a nuclear enterprise were adopted at the national level: the Law of the Belorussian SSR on Social Protection of Citizens Affected by the Catastrophe at the Chernobyl NPP (February 12, 1991), ${ }^{17}$ the Law of the Ukrainian SSR on Status and Social Protection of Citizens Affected

14 The Joint Protocol is designed to establish treaty relations between the Contracting Parties to the Vienna Convention and the Contracting Parties to the Paris Convention, and to eliminate conflicts that may arise from the simultaneous application of both Conventions to the same nuclear incident. In the case of a nuclear incident occurring in a nuclear installation, the applicable Convention shall be that to which it is a Party the State within whose territory the installation is situated (Article III, 2).

15 UN Doc. A/45/342 E/1990/102, July 9, 1990.

16 Since 1990, UN General Assembly has yearly adopted a resolution on the matter (since 1993 on a biennial basis, since 2007 on a triennial basis). In 1991, to expedite financial contributions towards the Chernobyl activities, the Chernobyl Trust Fund was established under the management of OCHA (Office for the Coordination of Humanitarian Affairs).

17 The Law of the Belorussian SSR of February 12, 1991 was aimed at protecting the rights and interests of citizens: a) who participated in the liquidation of the consequences of the Chernobyl disaster, b) who were resettled, and left for a new place of residence, c) who lived on the territory of radioactive contamination. Citizens residing/working on the territory of the Republic of Belarus were entitled to receive benefits and compensation for damage caused to their health and property as a result of the disaster at the Chernobyl NPP, see Demichev (2012) 67-74. 
by the Accident at the Chernobyl NPP (February 28, 1991), ${ }^{18}$ the Law of Russian Federation on Social Protection of Citizens Affected by Radiation in Consequence of the Accident at the Chernobyl NPP (May 15, 1991),${ }^{19}$ the Law of the USSR on Social Protection of Citizens Who Suffered in Consequence of the Chernobyl Catastrophe (May 12, 1991). ${ }^{20}$ These laws only indirectly tackled with ecological problems. ${ }^{21}$

On August 24, 1991, Ukraine gained independence and assumed full direct responsibility for the consequences of the Chernobyl disaster. Since then, the European Communities (CE, Euratom) and then the EU, ${ }^{22}$ have been at the forefront of efforts to help post-Soviet countries cope with the devastating consequences of the explosion, in particular through the TACIS (Technical Aid to the Commonwealth of Independent States) Programme. In 1993, the European Bank for Reconstruction and Development (EBRD) set up a Nuclear Safety Account (NSA) to gather international aid to mitigate the consequences of the explosion, dismantle the remaining operating reactors in Chernobyl and enhance safety checks in the post-Soviet region.

On April 26, 1995, the Verkhovna Rada of Ukraine adopted a Resolution addressing the Parliaments of the Countries of the European Community and the G7 to resolve the problems of liquidation of the consequences of the Chernobyl disaster and declared that the thirty-kilometer exclusion zone around the Chernobyl nuclear power plant had to be considered a unique world laboratory to strengthen international cooperation and to develop scientific technologies aimed at socio-economic rehabilitation of the contaminated areas. ${ }^{23}$

18 The Law of the Ukrainian SSR of February 28, 1991 was aimed at protecting the citizens affected by the Chernobyl disaster and addressing the medical and social problems arising from radioactive contamination of the territory. It defined the categories of zones of radioactively contaminated territories; guaranteed the right of citizens to emigrate from contaminated territories and the right to information on the levels of contamination by radioactive substances of terrains; identified the categories of persons affected by the Chernobyl disaster and their rights, see Malyuga (2013) 264-70.

19 The Law of Russian Federation of May 15, 1991, was aimed at defining state policy in the field of social support for citizens of the Russian Federation who were affected by adverse factors that arose as a result of the Chernobyl disaster, or who had taken part in activities for eliminating the consequences of this disaster. This Law guaranteed to the citizens compensation for damage caused to their health and property, and compensation for the risk of living and working in the territory exposed to radioactive contamination exceeding the admissible levels, see Belyaninova (2014).

20 This Law was aimed at protecting the rights and interests of citizens of the USSR who suffered as a result of the Chernobyl disaster, who participated in the liquidation of the Chernobyl accident and its consequences, who were evacuated or moved to a new place of residence from radioactively contaminated territories. It regulated the regime of the territory exposed to radioactive contamination as a result of this disaster, the living conditions and medical care of the population, the conduction of economic, scientific and other activities, see Baranovskaya, Yukiko (2017) 67-84.

21 'However, in comparison to the legal vacuum that in fact existed during five years after Chernobyl, these laws were a significant step forward', see Zgersky (1998) 266-70.

22 It might be useful to recall that the EC - European Community and the EU - European Union were established by the 1992 Maastricht Treaty. Following the 2007 Treaty of Lisbon, amending the Treaty on EU and the Treaty establishing the EC, the Union has replaced and succeeded the EC (cf. Article 1, 3, of the consolidated version of the Treaty of EU).

${ }^{23}$ In this Resolution, the Verkhovna Rada stated that Ukraine is expecting on strengthening international cooperation, pooling of intellectual and material resources of the world community, of international organizations, scientific and business circles, interested individuals in order to overcome the consequences of the Chernobyl catastrophe, including the removal of the threat arising from the 
A few months later, on December 20, 1995, a Memorandum of Understanding (MoU) between the Government of Ukraine, the Commission of the European Community and the Governments of the G-7 on the Closure of the Chernobyl Nuclear Power Plant was signed. According to this MoU, Ukraine, with the support of the international community, had to implement at the state level the entire complex work on the decommissioning of the Chernobyl nuclear power plant.

Then, Ukraine, the European Commission and the G-7 agreed to establish a multilateral funding mechanism, the Chernobyl Shelter Fund, to finance the transformation works of the existing sarcophagus into a stable and environmentally safe system through the Chernobyl Shelter Implementation Plan. On November 20, 1997, the Framework Agreement between Ukraine and the EBRD concerning the activities of the Chernobyl Shelter Fund was signed. The EBRD was entrusted with managing the Fund, the Ministry of Foreign Affairs of Ukraine of coordinating the international cooperation.

In parallel, the treaty rules concerning liability were revised to overcome the inadequacies illustrated by the Chernobyl and to ensure that in all countries affected by a nuclear accident victims would be accorded equitable compensation for damage suffered. The Protocol to Amend the Vienna Convention, aimed to provide for increased amount of liability of the operator of a nuclear installation and enhanced means for securing adequate and equitable compensation (September 12, 1997, in force since 3.10.2003) ${ }^{24}$ and the Protocol to Amend the Paris Convention (February 12, 2004; not yet in force) were adopted.

Ukraine's accessed the Vienna Convention on Civil Liability on September 20, 1996 (entered into force in the national legal system on December 20, 1996) and the Joint Protocol relating to the Application of the Vienna Convention and the Paris Convention on March 24, 2000 (entered into force on June 24, 2000). It is not a party of the Protocol to Amend the Vienna Convention.

In addition, IAEA also expanded safety standards and several international legal instruments were adopted to enhance nuclear safety and emergency preparedness and response, such as the Vienna Convention on Nuclear Safety (June 17, 1994; entered into force October 24, 1996), which applies to the safety of nuclear installations (Article 3, Scope of application $)^{25}$ and the Joint Convention on the Safety of Spent Fuel Management and on the Safety of Radioactive Waste Management (September 5, 1997; entered into force June 18, 2001), which complemented the Convention.

Ukraine ratified both the instruments: the Convention on Nuclear Safety on April 8, 1998 and the Joint Convention on the Safety of Spent Fuel and Radioactive Waste Management July 24, 2000 (they entered in force in the national legal system respectively on July 7, 1998 and June 18, 2001). The Declaration accompanying the ratification of the

removal of radionuclides outside the contamination zones, and reform of the energy sector in Ukraine. Such an approach would bring the greatest benefit to the world community and the people of Ukraine, see Ratushnyi (2010) 299-312.

24 On 2004, it was adopted also the Protocol to Amend the Brussels Supplementary Convention, not yet in force.

${ }^{25}$ For the purpose of this Convention: (i) 'nuclear installation' means for each Contracting Party any land-based civil nuclear power plant under its jurisdiction including such storage, handling and treatment facilities for radioactive materials as are on the same site and are directly related to the operation of the nuclear power plant. Such a plant ceases to be a nuclear installation when all nuclear fuel elements have been removed permanently from the reactor core and have been stored safely (Article 2, Definitions). 
Convention on Nuclear Safety however, excluded from the scope of application of the Convention the 'Shelter' remaining as a result of the consequences of the Chernobyl catastrophe, because 'at present, no technologies exist for transforming the Shelter into an ecologically safe system ... under these circumstances, Ukraine is not able by itself to resolve this large-scale problem in the shortest possible time and is counting on the assistance of the IAEA, international organizations and individual States in tackling the scientific and technological issues involved in ensuring the safety of the Shelter'.

In 2000, the Ukrainian government eventually shut down the three still operative reactors of the plant. Both the UN General Assembly, with Resolution no. 55/171 of December 14, 2000, on Closure of the Chernobyl Nuclear Power Plant, ${ }^{26}$ and Ukraine, with Decision of December 15, 2000, ${ }^{27}$ confirmed the decision to close the Chernobyl NPP.

The overview carried out of the various acts adopted in the period following the accident up to 2000 seems to show that this first phase of international cooperation on Chernobyl was characterized on one hand, by the objectives of environmental protection and restoration, humanitarian assistance and health control and on the other hand, by the broadening and strengthening of the treaty law in the sector of nuclear energy.

\section{THE SECOND PHASE OF THE INTERNATIONAL COOPERATION}

In 2001, the UN adopted a new strategy, with a focus on long-term developmental approach. The UNDP and its regional director for the three affected countries, Belarus, the Russian Federation and Ukraine, became part of the coordination mechanism for Chernobyl cooperation.

The UN General Assembly Resolution no. 62/9 of November 20, 2007 proclaimed the third decade after the Chernobyl disaster (2006-2016) as the Decade of Recovery and Sustainable Development of the Affected Regions, aimed to the strengthening of international cooperation and coordination of efforts to return affected communities to normal life. ${ }^{28}$ The Resolution assigned to the UNDP the coordination of these efforts. In 2008, the UN Action Plan on Chernobyl until 2016 was adopted.

The EU continued to act as the main donor to the post-Chernobyl accounts of the EBRD, funding major remediation projects, including the building of the new sarcophagus for the reactor.

26 The General Assembly calledupon the international community to continue to assist the Government of Ukraine in coping with the range of newly emerging economic and social problems arising as a result of the closure of the Chernobyl NPP, A/RES/55/171, February 26, 2001.

27 On December 15, 2000, by order of the President of Ukraine, by turning of the key of emergency protection of the fifth level (AZ-5), the reactor of the Chernobyl NPP Unit 3 was stopped permanently and the station stopped generating electricity.

${ }^{28}$ UN GA Resolution on Strengthening of international cooperation and coordination of efforts to study, mitigate and minimize the consequences of the Chernobyl disaster (A/RES/62/9, December 18 , 2007). The Resolution stressed the need for improved resource mobilization by the UN system to support activities aimed at the recovery of Chernobyl-affected territories, through, inter alia, community-based development projects, the promotion of investment and the creation of new jobs and small businesses. It also noted assistance rendered by the IAEA to Belarus, the Russian Federation and Ukraine on remediation of agricultural and urban environments, and cost-effective agricultural countermeasures. 
In 2014, the Association Agreement between the EU and its Member States, of the one part and Ukraine, of the other part, regulated the development of the sector cooperation; the overcoming the consequences of the Chernobyl disaster, ${ }^{29}$ as well as the decommissioning of the nuclear power plant.

According to Article 342, 2, the cooperation in the civil nuclear sector has to ensure, through the implementation of specific agreements, 'a high level of nuclear safety, the clean and peaceful use of nuclear energy, covering all civil nuclear energy activities and stages of the fuel cycle, including production of and trade in nuclear materials, safety and security aspects of nuclear energy and emergency preparedness, as well as health-related and environmental issues and non-proliferation'.

Various activities were carried out based on these provisions of the Association Agreement. Among them, in 2015 the Ukrainian Government approved plans for the implementation the Euratom Directives no. 2013/59 (basic safety standards relating to protection against the risks deriving from exposure to ionizing radiation), no. 2006/117 (surveillance and control of shipments of radioactive waste and spent nuclear fuel) and no. 2014/87 (Community framework for nuclear safety of nuclear installations). ${ }^{30}$

At the bilateral level, the aims of scientific research and safe management of the area were the basis of other cooperation activities. Among them, the Agreement between the Cabinet of Ministers of Ukraine and the Government of the Kingdom of Norway on Cooperation in the field of nuclear and radiation safety, decommissioning of the Chernobyl nuclear power plant and transformation of the Shelter Object into an environmentally friendly burning system (Oslo, November 30, 2012).

\section{THE CURRENT PHASE OF INTERNATIONAL COOPERATION}

At the end of the third decade, the General Assembly, with its Resolution no. 71/125, in order to raise awareness of the long-term consequences of the accident, designated 26 April as International Chernobyl Disaster Remembrance Day, to be observed every year beginning in 2017. ${ }^{31}$ Moreover, the General Assembly affirmed the objective of achieving the Sustainable Development Goals (SDGs) in the Chernobyl affected regions. ${ }^{32}$

It is our opinion that this GA Resolution opened a new phase of cooperation on Chernobyl, in which the SDGs agreed in 2015 by the international community constitute the paradigm guiding the initiatives to benefit of the area and the populations

${ }^{29}$ In particular, those concerning the de-contamination of the territories; radioactive waste management; and monitoring of the environment, Article 342, 3, Title V - Economic and Sector Cooperation, Chapter 1 - Energy cooperation, including nuclear issues.

30 Report on Implementation of the Association Agreement (2019).

31 UN GA Resolution no. 71/125on Persistent Legacy of the Chernobyl Disaster, A/71/125, 19 December 2016.

32 In October 2015, the UN GA adopted the 2030 Agenda for Sustainable Development, which establishes a global framework for the eradication of poverty and the attainment of sustainable development. The Agenda defines a universal Action Programme, articulated in 17 Sustainable Development Goals - SDGs, and 169 associated goals, which require for their achievement the mobilization of all interested countries and parties. Transforming Our World: The 2030 Agenda for Sustainable Development, UN A/Res/70/1, 21 October 2015, at http://www.un.org/ga/search/view doc.asp?symbol=A/RES/70/1\&Lang=E. In particular, it affirms the aim to ensure access to affordable, reliable, sustainable and modern energy for all, and, by 2030, increase substantially the share of renewable energy in the global energy mix (Goal 7). 
concerned. These initiatives (which are not necessarily labelled as 'Chernobyl Projects') focus on promoting green growth, conserving biodiversity, preventing land degradation and forest fires, enhancing energy efficiency, improving local governance systems. ${ }^{33}$

At the bilateral level, it is worth to mention the MoU between the Chernobyl Research and Development Institute and the Institute for Environmental Radioactivity of the University of Fukushima, Japan (February 6, 2017). The Chernobyl - Fukushima Programme formulated in this $\mathrm{MoU}$ is to disseminate the experience of eliminating the consequences of the Chernobyl accident, systematize the received practical knowledge, as well as its application to overcome the consequences of the accident in Fukushima. ${ }^{34}$

Lastly, the most important activity carried out by the international cooperation since 2000 , the construction of the new shelter, was completed. The giant arch-shaped steel structure, designed to remain functional for 100 years, was constructed in two halves near the accident site from 2010 to 2016 and eventually slid over the existing sarcophagus via rails.

According to the EBRD, the New Safe Confinement shielding the destroyed reactor 4 costed $€ 1.5$ billion and was financed by 45 donor countries and institutions. It was subjected to functional tests and has become operational in 2019. ${ }^{35}$

The keys for the New Safe Confinement were symbolically presented to the Ukrainian authorities on July 10, in a ceremony attended by the President Volodymyr Zelenskyy. The structure, representing the largest ever example of international cooperation in the field of nuclear safety, is the most prominent component of the $€ 2.1$ billion Shelter Implementation Plan, which includes the completion of crucial infrastructure and other safety projects.

\section{THE IMPACT OF THE CHERNOBYL ACCIDENT ON THE DEVELOPMENT OF NUCLEAR ENERGY POLICIES}

Analysing the evolution of the international cooperation on Chernobyl, it seems possible to make some observations on the impact of the accident had on the definition of the nuclear energy policies, which has been different in the various countries.

In Italy, for example, the Chernobyl disaster influenced the public opinion and the same definition of basic energy policy choices, by contributing to the adoption - following a referendum held in 1987 - of a decision of a moratorium on the use of the nuclear source. ${ }^{36}$ The 1988 Italian National Energy Plan (PEN) signed the end of the development

33 UN Secretary-General (2016).

34 This Programme is implemented with the assistance of the Japan International Cooperation Agency (JICA). The purpose of the Programme is to find answers to global challenges. The first stage of the cooperation program is for 5 years. The creation of three new research sites in the exclusion zone is foreseen. Cf. $<$ http://chornobyl.institute/ua/our-projects/2017/08/15/28/view $>$ accessed 12 February 2019.

35 D. La Cecilia, Ambassador in Kiev, highlighted that Italy has contributed over the years to the safety of the Chernobyl site with a sum close to 100 million Euros, paid to the ad hoc funds set up by the EBRD. Cf. <http://www.rainews.it/dl/rainews/articoli/Chernobyl-si-completa-messain-sicurezza-Cerimonia-per-traslazione-arco-forte-contributo-Italia-e03ca502-3b69-474b-b40b 6ec602a1fd41.html?refresh_ce> accessed 2 February 2019.

36 The debate on the possible reintroduction of nuclear energy, which opened in 2005, ended with a new referendum held in 2011. 
of sector production; the four existing nuclear power plants (Latina, Sessa Aurunca, Trino, Caorso) were closed.

Of particular relevance the follow up of the Chernobyl accident in Germany, where anti-nuclear movements were active since the 1970s and the debate on the concept of Energiewende dates back to the early 1980s. Germany progressively developed plans to move from fossil fuel-based energy generation to a largely carbon-free energy sector and in this framework to phase out nuclear energy. The Nuclear Phase-Out Act (Act on the Controlled Phasing Out of the Use of Nuclear Power for the Commercial Generation of Energy) was adopted on April 22, 2002.

The key act outlining the Energiewende was the Energy Concept 2050, presented by the Conservative / Liberal coalition in September 2010, followed by the $11^{\text {th }}$ Amendment to the Atomic Energy Act (December 8, 2010). After Fukushima, on March 14, 2011, the Federal Chancellor, Angela Merkel, announced a 'moratorium' involving a suspension of operation of the seven oldest nuclear power plants and the permanent decommissioning of the Krümmel plant. ${ }^{37}$ On July 13, 2011, the $13^{\text {th }}$ Amendment to the Atomic Energy Act was adopted, which permanently decommissioned the NPPs shut down under the moratorium and set a date for the final shutdown of each of the other NPPs. ${ }^{38}$

The German policy targets concerning the reduction of greenhouse gas emissions, the development of renewable energy and energy efficiency go beyond those established in the EU legislation.

In Hungary, following the Fukushima Daiichi accident, the Government said it would conduct a stress test on the Paks NPP to assess safety but would not abandon plans for lifetime extension. It would also go ahead with plans for its expansion. ${ }^{39}$ Unit 1 of the Paks NPP was granted a license-extension to 2032 in 2012, Unit 2 to 2034 in 2014, Unit 3 to 2036 in 2016 and Unit 4 until 2037 in 2017. In addition, according to an agreement signed on January 14, 2014, Paks NPP will be expanded. On March 6, 2017, the European Commission approved the project, construction of two reactors by the Russian state company Rosaton started in 2019.

Passing to the most affected countries, in Belarus, the question of building a nuclear power plant was raised out in the early 1990s. On November 2, 2013, President A. Lukashenko signed Decree no. 499 on the Construction of the Belarusian Nuclear Power Plant, which allowed the general contractor, Russian Atomstroy export, to begin the construction of the Belarusian NPP. The chosen site is located on the northwestern border of Belarus, 18 kilometers from the city of Astrovets, Grodno region, and $50 \mathrm{~km}$ from Vilnius, the capital of Lithuania. Lithuania is in fact strongly opposing the construction of

37 Germany immediately closed some reactors and for the eight remaining in operation, a closure plan was defined: 1 reactor was closed at the end 2017 and 7 will be closed between 2021 and 2022, Clerici (2018).

38 Mann (2014) 43-75. On August 1, 2014, a revised Renewable Energy Source Act entered into force.

39 In Hungary, the existing nuclear units are located in a site 5 kilometres far from Paks, about $100 \mathrm{~km}$ south of Budapest. The four reactors of the Paks power plant started up between 1982 and 1987. Originally, these plants had expected lives of 30 years. In 2000, a feasibility study concluded that the plant may remain in operation for another 20 years beyond the original 30-year design lifetime. In 2005, the study was updated and the Hungarian Parliament passed a resolution to support the lifetime extension. Cf. <https://www.sunpp.mk.ua/uk/nuclear/world_power_engineering $>$ accessed 2 February 2019. 
this NPP, also considering that, following a referendum held in 2012, it stopped the project for the construction of a new NPP at Ignalina.

In the Russian Federation there are 10 active nuclear power plants. Eleven of the operating reactors are of the RBMK 1000 type, similar to the one at the Chernobyl NPP. Russia has also made plans to increase the number of reactors. ${ }^{40}$

In Ukraine there are four nuclear power plants, Zaporozhye, South-Ukrainian, Rivne, Khmelnytsky, which have a total of 15 power units with a capacity of $13,835 \mathrm{MW}$. They provide production of almost half of the total state electricity. By 2020, the project lifetime will end for various operating NPP units. ${ }^{41}$ The Government of Ukraine has decided to extend the working life of these NPPs for another 10-20 years. ${ }^{42}$

On the global level, there are 448 nuclear reactors in operation in the world (IAEA data), including some reactors of the same type as the one destroyed at Chernobyl. ${ }^{43}$

\section{THE UKRAINIAN CONSTITUTION}

Turning now the national legal system, it is important to highlight that the Ukrainian Constitution of June 28, 1996, contains a provision concerning the protection of human health and the environment of great worldwide interest. Article 16 of the Constitution states in fact, that ensuring the ecological safety and maintenance of ecological balance on the territory, overcoming the consequences of the Chernobyl catastrophe and preservation of the gene pool of the people are the responsibility of the State.

This article has been inspiring some case law. Among the most recent and relevant, the sentence of the Constitutional Court of July 17, 2018 in a case concerning some provisions of the Law no. 76 of December 28, 2014 on Amendments and Recognition as Lack of Validity, Certain Legislative Acts of Ukraine. The Court affirmed that the State's duty envisaged in Article 16 of the Constitution to overcome the consequences of the Chernobyl disaster and preserve the Ukrainian national gene pool, determines the granting of a special status to the citizens who suffered as a result of the catastrophe.

According to the Court, the level of social protection of victims of the Chernobyl disaster should be such as to provide them with a dignified life. The possible abolition of benefits, compensations and guarantees for persons who suffered as a result of the disaster would not correspond to this duty of the State. Therefore, this people are constitutionally protected with respect to any negative consequences deriving from changes in the legislation.

40 Currently, six new nuclear power reactors are under construction. The Russian Federation is taking part in the construction of new NPPs in China, India and the Islamic Republic of Iran. Agreements on the development of nuclear power production were signed with Belarus, Finland and Hungary. Cf. IAEA, Country Nuclear Power Profiles, Russian Federation, https://cnpp.iaea.org/ countryprofiles/Russia/Russia.htm, updated 2019.

${ }^{41}$ Seven blocks have already served their 30 -year project resource and have undergone a special repair to extend the life of the operation. As a result, the work of some power units has been extended for 10 years, others - by 20, Klimchuk, Gubar (2017).

42 Although power units are undergoing modernization, part of the most important equipment, such as the reactor case, cannot be replaced. There are doubts as to how safe they are. According to an opinion, it is impossible to predict when one of the blocks will have to be stopped and what will be the consequences, Golovko (2018).

43 Chernobyl: gli effetti dopo 30 anni (2016). 
The Court emphasized that the necessity of preserving the gene pool of the Ukrainian people stated in Article 16 is primarily due to the ecological situation caused by the catastrophe, which resulted in deterioration of the population's health, demographic decline, illness of children, raising the level of disability of the population. ${ }^{44}$

The case and the sentence not only appear to be of great importance, but confirm the real and profound connection between environmental, social and economic problems that has found expression in the principle of sustainable development in international and European law.

\section{SPECIAL LEGAL REGIME OF THE TERRITORY EXPOSED TO RADIOACTIVE CONTAMINATION}

The basic legal acts adopted in Ukraine for the management of the Chernobyl area: The Law on the legal regime of the territory that was exposed to radioactive contamination as a result of the Chernobyl disaster (February 27, 1991); ${ }^{45}$ the Law on the general principles for the further exploitation and decommissioning of the Chernobyl nuclear power plant and the conversion of the destroyed fourth power unit of this NPP on an ecologically safe system (December 11, 1998). ${ }^{46}$

It is also to mention the National Programme for overcoming the consequences of the Chernobyl disaster for 2006-2010 (approved by the Law of March 14, 2006); ${ }^{47}$ the National Programme for the decommissioning of the Chernobyl nuclear power plant and the transformation of the Shelter object into an environmentally safe system (January 15, 2009). ${ }^{48}$

44 The Court affirms the State's obligation to preserve the gene pool requires an adequate amount of public expenditures, in particular, in the sphere of health care and social security; maintaining the sanitary and epidemiological well-being of the population in an appropriate condition, creating effective measures for the prevention of diseases; reducing the risks to human health, which are related to the radioactive contamination of a large area.

45 The Law of Ukraine of February 27, 1991 regulates the issues of division of the territory which was subject of radioactive contamination as a result of the Chernobyl disaster, into defined zones, the regime of their use and protection, and the living and working conditions of population. It establishes and guarantees the regime of use and protection of these zones in order to reduce the effect of radioactive radiation on human health and environmental systems, see Lysanets (2017) 61-64.

46 The purpose of the Law of Ukraine of December 11, 1998 was to regulate the peculiarities of legal relations during the further operation and early decommissioning of Chernobyl NPP units, and ensure social protection of Chernobyl NPP personnel, as well as peculiarities of taxation of related activity of business entities, see Nasvit (2016).

47 The National Programme for overcoming the consequences of the Chernobyl disaster for 2006-2010 envisaged measures for: a) further social, medical and psychological rehabilitation of the population and its radiation protection, b) completion of the economic revival of settlements and territories outside of the exclusion zone, and places of residence of resettled citizens, c) preservation of their cultural and historical heritage.

48 The National Programme for the decommissioning of the Chernobyl nuclear power plant and the transformation of the Shelter object into an environmentally safe system, introduced provisions about the necessary funding, as well as organizational and technical tasks. It has also defined priority measures to be taken during 2019-2020 at the stage of the Chernobyl NPP shutdown and transformation of the Shelter facility. 
The 1991 Law on the legal regime of the territory that was exposed to radioactive contamination applies to the territories

(a) where there was a constant pollution of the environment by radioactive substances above the pre-accidental level, taking into account naturally-climatic and integrated ecological characteristics of specific territories that can lead to irradiation of the population more than $1.0 \mathrm{mSv}$ (sievert $)^{49}(0.1 \mathrm{rem})^{50}$ per year,

(b) which require measures for radiation protection of the population and other special interventions directed at the necessity of limiting additional radiation exposure of the population caused by the disaster and ensuring its normal economic activity. ${ }^{51}$

The territory so delimited is divided into zones depending on the landscape and geochemical characteristics of the soils, the level of exceeding the natural accidental level of accumulation of radionuclides in the environment, the associated degrees of possible adverse effects on the health of the population, requirements for the implementation of radiation protection of the population and other special measures, taking into account the general production and social and communal relations.

These zones are:

1) the exclusion zone, which is the territory from which the evacuation of the population was carried out in 1986 ;

2) the zone of unconditional (mandatory) resettlement, which is a territory that was subjected to intense pollution with long-lived radionuclides, with a density of soil contamination above the pre-accident level of cesium isotopes of $15.0 \mathrm{Ci}^{52} / \mathrm{km}^{2}$ and above, or strontium from $3.0 \mathrm{Ci} / \mathrm{km}^{2}$ and above, or plutonium from $0.1 \mathrm{Ci} / \mathrm{km}^{2}$ and above, ${ }^{53}$ where the estimated effective equivalent dose of human radiation, taking into account the coefficients of migration of radionuclides in plants and other factors, may exceed $5.0 \mathrm{mSv}$ $(0.5 \mathrm{rem})$ per year over the dose it received in the pre-accident period;

3 ) the zone of guaranteed voluntary resettlement, which is a territory with a density of soil contamination above the pre-accident level isotope cesium from 5.0 to $15.0 \mathrm{Ci} / \mathrm{km}^{2}$, or strontium from 0.15 to $3.0 \mathrm{Ci} / \mathrm{km}^{2}$, or plutonium from 0.01 up to $0.1 \mathrm{Ci} / \mathrm{km}^{2}$, where the estimated effective equivalent dose of human radiation, taking into account the coefficients of migration of radionuclides in the plant and other factors, may exceed $1.0 \mathrm{mSv}(0.1 \mathrm{rem})$ per year more than the dose it received during the pre-accident period.

49 The sievert (symbol: $\mathrm{Sv}$ ) is a derived unit of ionizing radiation dose in the International System of Units (SI) and is a measure of the health effect of low levels of ionizing radiation on the human body.

50 The roentgen equivalent man (or rem) is an older, CGS (centimeter - gram - second system) unit of equivalent dose, effective dose, and committed dose which are measures of the health effect of low levels of ionizing radiation on the human body.

51 In Belarus, the Chernobyl exclusion zone was created by the Law of November 12, 1991, on legal regime of territories exposed to radioactive contamination in consequence of the catastrophe at the Chernobyl NPP. Now, the legal regime of territories contaminated by nuclear catastrophe is regulated by the Law no. 385-3 of May 26, 2012, on legal regime of territories exposed to radioactive contamination as a result of the Chernobyl disaster.

In the Russian Federation, the legal regime of the territories contaminated after the accident is defined by the Lawon social protection of citizens exposed to radiation as a result of the disaster at the Chernobyl nuclear power plant of July 29, 2018.

52 The curie (symbol Ci)is a unit of radioactivity originally defined in 1910.

53 The main radionuclides that determine the pollution of the exclusion zone are cesium-137, strontium-90, and alpha-emitting trans uranium elements. 
The most polluted is the territory of the exclusion zone, from which, in 1986, the population was evacuated. ${ }^{54}$ In 1998, part of the zone of unconditional (mandatory) resettlement was annexed to the territory of the exclusion zone and now the total area of the exclusion zone is 2598 square kilometers. ${ }^{55}$

This legislation definitely ensures a special legal regime to the territories exposed to radioactive contamination, which constantly undergoes revision and updating. The Law of February 28, 2019 on the Principles (Strategy) of the State Environmental Policy of Ukraine for the Period up to $2030,{ }^{56}$ declares that land, water and forest resources of the exclusion zone and the zone of mandatory resettlement, which serve as a natural barrier to the spread of radioactive contamination beyond their limits, require constant monitoring and use in compliance with radiation safety requirements.

\section{THE ZOOLOGICAL PRESERVE OF NATIONAL IMPORTANCE 'CHERNOBYL SPECIAL'}

Passing to the analysis of the state policy in the field of environmental protection and ecological safety, it is based on the Law on the Nature Reserve Fund of Ukraine (June 16, 1992), ${ }^{57}$ which provides for the establishment of the territories and objects of the national Nature Reserve Fund. Within such territories and objects, only the types of activities specified in the respective regulations can be carried out.

Territories and objects of the Nature Reserve Fund may be created in the exclusion zone and in zone of mandatory resettlement, in order to carry out scientific research in the field of environmental protection, preservation of natural diversity of landscapes, gene pool of animal and plant life, maintenance of the overall ecological balance, provision of monitoring of the environment.

${ }^{54}$ Characteristic of the exclusion zone are: a) the high density of radionuclides on the surface of the earth and their high concentration in surface waters; b) presence of large localized sources of radioactivity (Shelter object, burial places and temporary localization of radioactive waste); c) forming within the territory of the main part of the pollution of the runoff of the Dnieper River; d) special landscape conditions that contribute to increasing the migration of radionuclides by food chains; e) termination of traditional economic activity. National Program for Overcoming the Consequences of the Chernobyl Disaster for 2006-2010.

55 This territory belongs to the sphere of management of the State Agency of Ukraine on the Exclusion Zone Management (SAEZ), which is part of the Ministry of Ecology and Natural Resources of Ukraine.

56 The Law of February 28, 2019 declares that the aim of state environmental policy is to achieve good environmental status by introducing an ecosystem approach to all areas of socioeconomic development. The purpose is that of ensuring the constitutional right of every citizen to a clean and safe environment, introducing a balanced use of nature and preserving and restoring natural ecosystems. The Law defines strategic goals and objectives, instruments, stages of implementation of the state environmental policy, as well as for monitoring and evaluation of its implementation, and the achievement of the expected results, see Balyuk (2017) 8-15.

57 According to the Law of June 16, 1992 the Nature Reserve Fund consists of land and water areas, whose natural complexes and objects have special conservation, scientific, aesthetic, recreational and other value and are allocated in order to preserve the natural diversity of landscapes, gene pool of wildlife and ecological balance. On the basis to this legislation, the nature reserve fund is protected as a national property, for which a special regime of protection and use is established. Ukraine identifies this Fund as an integral part of the world's system of protected natural areas, see Malysheva (2008) 207. 
The special regime of such territories is defined in the regulations on them, approved in the light of both the Law on the legal regime of the territory that was exposed to radioactive contamination as a result of the Chernobyl disaster and the Law on the Nature Reserve Fund.

By the Decree of the President of August 13, 2007, on the announcement of the natural territory of the Zoological Preserve of National Importance 'Chernobyl Special', a natural area of 48,870 hectares within the exclusion zone and an area of mandatory resettlement was created. ${ }^{58}$

The purpose of creating such a 'preserve' (zakaznik) (59 $^{59}$ was to safeguard the unique properties of forest plantations within the Kyiv Polissya, the largest wildlife conservation area in Ukraine, which needs protection and regulation of the population. On the territories of preserve continuous passage, forests and gradual felling, removal of clogging, as well as hunting and other activities, which contradicts defined goals and tasks, are prohibited. Economic, scientific and other activities, which do not contradict these goals and objectives of the preserve, are carried out in compliance with the general requirements for the protection of the environment. ${ }^{60}$

However, the Cabinet of Ministers of Ukraine, failed to approve the regulation to make effective the establishment of the Zoological Preserve 'Chernobyl Special'.

\section{THE CHERNOBYL RADIATION AND ECOLOGICAL BIOSPHERE RESERVE}

The Law on the Nature Reserve Fund of Ukraine determines also the legal regime of biosphere reserves (BRs). They are nature protection, scientific research institutions of national importance, created for the purpose of preservation in the natural state of the most typical natural complexes of the biosphere, the implementation of a background

58 The natural vegetation occupies about $80 \%$ of the total area, see Dolin, Orlov.

59 Zakaznik is a type of protected area in former Soviet Republics such as Belarus, Russia, Ukraine, that meets World Conservation Union's (IUCN) Category IV, or more frequently Category VI criteria. Many zakazniks have traditionally been managed as game reserves; some protect complex ecosystems, colonies of birds, or populations of rare plants.

60 In Belarus, a nature reserve was established with a total area of $1,313 \mathrm{~km}^{2}$ on the territory of the three most affected areas of the Gomel region: Bragin, Narovlyansky and Khoiniki on July 18, 1988. Article 17 of the Law of May 26, 2012 on legal regime of territories exposed to radioactive contamination as a result of the Chernobyl disaster regulates the establishment and operation of the State Radiation Ecological Reserve, within the boundaries established. By the Decree of the President no. 41 of January 21, 2013, the Polesie State Radiation Ecological Reserve was transformed into the state environmental research institution Polessky State Radiation Ecological Reserve. On the territory there are 96 abandoned settlements, where before the accident lived more than 22000 inhabitants. The reserve area is $2,162 \mathrm{~km}^{2}$, making it the biggest Belarusian nature reserve and one of the biggest in Europe.

The legislation of the Russian Federation does not provide the creation of objects of nature reserve fund on the territories, affected by the accident at the Chernobyl NPP. At the same time, Article 12 of the Law on social protection of citizens exposed to radiation prescribes special measures for the environmental rehabilitation of the territory of radioactive contamination: scientific research; state environmental control and monitoring; state environmental assessment of economic and other activities; transformation of radiation contaminated areas to ecologically safe condition, suitable for economic use and livelihoods of the population. 
ecological monitoring, study of the environment and its changes under the influence of anthropogenic factors. ${ }^{61}$

These rules are in line with the 1971 UNESCO Man \& Biosphere Programme, which provides for the creation of BRs, intended as areas in which, through appropriate land management, both natural ecosystem and biodiversity conservation aims and sustainable use of natural resources are pursued.

'UNESCO' BRs are nominated by national governments and remain under the sovereign jurisdiction of the states where they are located. ${ }^{62}$ Given the particular importance of research activities in these areas, they can be considered 'science for sustainability support sites', special places for testing interdisciplinary approaches to understanding and managing changes and interactions between social and ecological systems, including conflict prevention and management of biodiversity. ${ }^{63}$

In 2006, on the occasion of the $20^{\text {th }}$ anniversary of the Chernobyl nuclear power plant disaster, a two-year Project for the Establishment of a Transboundary Biosphere Reserve (TBR) and a Regional Ecological Network in Polesie (an area in the southwest of the east European lowlands encompassing parts of Belarus, Poland, the Russian Federation and Ukraine) was launched. The Project was at once a Transboundary BR (TBR) under UNESCO MAB Programme and an ecological network in terms of the Convention on Biological Diversity and of its European component, the Pan-European Ecological Network (PEEN). Funded by the Government of Japan, it was involving Belarus, Poland and Ukraine with the aim of generating new scientific knowledge and contributed to the conservation of water resources and biodiversity.

In 2015, a new Project on: Conservation, Optimization and Management of Carbon and Biodiversity in the Chernobyl Exclusion Zone was launched. The objective of this

61 Within the reserves, based on functional zoning, territories are defined with differentiated legal regimes:

a) protected area - areas intended for the preservation and restoration of the most valuable natural and minimally disturbed anthropogenic factors of natural complexes, the gene pool of flora and fauna; its regime is determined in accordance with the requirements established for natural reserves

b) buffer zone - territories allocated for the purpose of prevention of negative influence on the protected area of economic activity in the adjoining territories; its regime is determined in accordance with the requirements established for protected areas of nature reserves

c) zone of anthropogenic landscape - areas of traditional land use, forest use, water use, settlements, recreation and other types of economic activity; hunting is prohibited.

In the project of the organization of the territory of the BR and the protection of its natural complexes, measures for the conduct of environmental protection, research, recreation, and economic activity in accordance with the legislation and international agreements are determined and grounded. Scientific research, and monitoring of the state of the environment are carried out considering international programs.

62 Andrian and Melen (2007) 245-70.

${ }^{63} \mathrm{Cf}$. http://www.unesco.org/new/en/natural-sciences/environment/ecological-sciences/accessed 19 April 2019. In the world, there are 701 BRs in 124 countries, including 21 transboundary sites. In Ukraine there are 8 BRs, 3 of them are transboundary: Danube Delta (Romania/Ukraine, established in 1998, former Dunaisky - 2010, 2015 joint report), East Carpathians (Poland/Slovakia/Ukraine, established in 1998 - 2014 joint report), and the West Polesie (Belarus/Poland/Ukraine, established in 2002, former Shatskiy, extended and renamed in 2012 - 2014). The other BRs are: Desnianskyi (2009), Roztochya (2011), Chornomorskiy (1984), Askaniya-Nova (1985), Carpathian (1992). 
UNEP-GEF Project ${ }^{64}$ was to assist Ukraine in establishment of a system of environmental protection activities within and around the Chernobyl exclusion zone (for the conservation of the valuable natural complexes of Polissya). An important task was the assistance in organization of the Chernobyl Radiation and Ecological BR, in particular the development of programs and activities of environmental protection, obtaining scientific information on the real value of certain zones, the number and distribution of rare species of plants and animals, problems and perspectives for their conservation, possible risks, etc.

Thereafter, various acts and programmes aimed to create a biosphere reserve on a radiation-contaminated territory were adopted. Among them, the Recommendation of the Parliamentary Hearings on the Decommissioning of the Chernobyl Nuclear Power Plant, the Shelter Object and the Prospects for the Development of the Exclusion Zone (approved by the Parliament on April 22, 2015) and the Recommendation of the Parliamentary Hearings on 30 Years after Chernobyl: Lessons and Perspectives (approved by the Parliament on April 13, 2016).

Finally, on the day of the $30^{\text {th }}$ anniversary of the disaster, the Decree of the President of Ukraine of April 26, 2016 created the Chernobyl Radiation and Ecological Biosphere Reserve. It includes territories within the exclusion zone and the zone of mandatory resettlement of the Ivankivskyi and Polissya districts of the Kyiv region. It confirms the great worldwide success of the UNESCO MAB programme.

The Chernobyl Radiation and Ecological Biosphere Reserve was regulated by the Order of the Ministry of Ecology and Natural Resources dated February 3, 2017. It comprehends the abovementioned Zoological Preserve of the National Significance Chernobyl Special, created in 2007.

The total area of the BR is 226964, 7 hectares of state-owned land, which are transferred to the biosphere reserve for permanent use. Land and water areas with natural resources are completely withdrawn from economic use.

The purpose of the Chernobyl Radiation and Ecological BR are

a) to preserve in the natural state the most typical natural complexes of Polissya,

b) to increase the barrier function of the Chernobyl exclusion zone and the zone of mandatory resettlement,

c) to stabilize the hydrological regime and rehabilitation of areas contaminated with radio nuclides,

d) to assist in the organization and conduct of international scientific research.

The main tasks are:

- stabilization of the hydrological regime and rehabilitation of territories contaminated with radionuclides;

- assistance in the organization and conduct of international scientific research; minimization of ecological danger and preservation of natural resources of the exclusion zone and zone of mandatory resettlement;

- preservation in the natural state of the most typical natural complexes of Polissya;

- reproduction and conservation of natural ecosystems; implementation of scientific research in the field of environmental protection;

${ }^{64}$ The main partners of the Project are: the UN Environment Program (UNEP), the Global Environment Facility (GEF), the Ministry of Ecology and Natural Resources of Ukraine, and the State Agency of Ukraine for the Management of the Exclusion Zone, <http://chornobyl-gef.com/en/tasksof-the-reserve.html>accessed 15 April 2019. 
- preservation of natural diversity of landscapes, gene pool of animal and plant world, maintenance of general ecological balance;

- prevention of radionuclide removal from the territory of zones and radioactive contamination of the environment;

- monitoring of the state of the environment and medical-biological monitoring;

- carrying out of ecological educational work, etc.

The Biosphere Reserve is included in the World Network of BRs under the UNESCO MAB Programme. ${ }^{65}$ It can be increased to the south-west, where the Drevlyanskyy Reserve is located and also to Belorussia to Paleski Radio-Ecological Reserve. This huge planned UNESCO BR will get a chance to naturally rewind and has the chance to become the biggest nature conservation territory in Europe. ${ }^{66}$

On July 5, 2018 a special Decree of the President on Additional measures for the revival of territories affected by radioactive contamination, as a result of the Chernobyl disaster, on social protection of victims, safe management of radioactive waste provided further measures to ensure the effective establishment and the operating of the Chernobyl Radiation and Ecological BR. It foresaw the necessity to provide in the legislation the features of the nature protection regime of the territories and objects of the Nature Reserve Fund included in the exclusion zone and in the zone of mandatory resettlement. ${ }^{67}$

Confirming the sharing of post nuclear accidents issues and challenges, the Decree underlined the importance of deepening of international cooperation with the Government of Japan on the issues of the rehabilitation and development of areas exposed to radioactive contamination, the implementation of scientific projects in the field of environmental protection, the exchange of experience and training in the framework of such cooperation, including the establishment of cooperation at the level of the concerned regions.

Finally, the new President of Ukraine, Volodymyr Zelenskyy, adopted Decree no. $512 / 2019$ of July 10, 2019 on Some issues of the development of territories affected by radioactive contamination as a result of the Chernobyl disaster.

This Decree confirms the fundamental aims of stimulating the revival of territories affected by radioactive contamination and supporting nature conservation activities. It also highlights the importance of creating the conditions for the use of their tourist potential, also through the approval and launch of the 'Safe Chernobyl' brand.

According to the Decree, the Cabinet of Ministers of Ukraine should take various actions with a strict timetable (in three months). In particular, among others, it should take measures aimed at improving the conditions for visiting the exclusion zone and the zone of mandatory resettlement and for the development of tourism in these territories, in particular promoting the new 'Safe Chernobyl' direction on the international tourist market; prepare and submit to the Verkhovna Rada draft laws, including on revision of the legal regime of zones of radioactively contaminated territories as a result of the Chernobyl disaster and the expediency of certain restrictions and prohibitions on the pursuit of activities in such areas.

65 Tamburelli (2012) 96-101.

66 Shchoka (2016).

${ }^{67}$ In particular, in order to promote the development of the BR as a unique natural-protected object, the Decree provides for: carrying out work on radio ecological monitoring of areas affected by radioactive contamination; completion of work on the establishment of boundaries and the preparation of documentation on land management, registration of the right of permanent use of land within the boundaries of the BR; studying the issue of improving the management and functioning of the BR, taking into account the special conditions and the regime of the protected areas that are part of it. 
With regard to the Chernobyl radiation and ecological BR, the Cabinet of Ministers should feature its functioning, specifying, in particular, the nature protection regime and the organizational and legal form of the management and functioning of the reserve. It should also ensure the completion of the work on the establishment of the boundaries of the BR, providing also for the production of documentation on land management and the registration of rights to land within the reserve.

\section{THE IMPACT ON INTERNATIONAL LAW}

It is now possible to make some further observations on the interrelationships between international environmental law and the activities carried out after the Chernobyl accident. In this regard, it is to highlight that principles, rules, objectives and programmes concerning environmental protection have been substantially evolving.

The key principle of 'sustainable development', understood as economic growth which does not affect negatively to any significant degree the environmental heritage, was elaborated only towards the end of 1987 by the UN Brundtland Commission, in a wideranging Report on Our Common Future. ${ }^{68}$ Thereafter, this principle, which will become the basic principle also of the cooperation on Chernobyl, as well as of Ukrainian related legislation, was definitely affirmed by the 1992 UN Conference on Environment and Development (UNCED, Rio de Janeiro), which hailed the idea that protection of the environment and economic growth are indissolubly linked and by the 1997 UN GA Special Session (UNGASS), which extended the principle to comprehend the safeguarding of social needs.

The Rio Conference and UNGASS were followed by a number of international conferences, by the setting of a complex treaty system and by the adoption at all levels of various types of acts concerning the protection of the environment. It seems sufficient here to recall the 2000 Millennium Declaration, the 2002 World Summit on Sustainable Development - WSSD (Johannesburg), the 2012 UN Conference on Sustainable Development - UNCSD (known as Rio+20). In 2015, an important part of this international legal and policy framework has been renewed with the adoption of the above mentioned 2030 Agenda for Sustainable Development. ${ }^{69}$

The Resolutions of the UN human rights bodies started to affirm the human right to live in a sound and healthy environment in $1988^{70}$ and the UN General Assembly explicitly recognized the right of each person to a healthy environment only in $2010 .{ }^{71}$ However, in

68 World Commission on Environment and Development - WCED (1987).

69 'The international law on environment and sustainable development has remained substantially at a standstill, on the plane of principles and laws of a general nature, at the framework shaped in the last decade of the last century, that is, at the ' 92 Rio Conference and the ' 97 UNGASS. Ultimately, in spite of the (apparently) profuse commitments at international level, the effectiveness of the law and policies continues to appear to be modest', Tamburelli (2016).

70 UN Sub-Commission on Human Rights, Res. 1988/26 (Sept. 1) and UN Commission on Human Rights Res. 1989/42 (Mar. 6). In 1990, the Commission on Human Rights adopted resolution 1990/41 entitled 'Human rights and the environment' in which it underscored the link between the preservation of the environment and the promotion of human rights.

${ }^{71} \mathrm{~A} / \mathrm{RES} / 64 / 157$ (March 8, 2010) affirms in paragraph 4 that 'a democratic and equitable international order requires, inter alia, the realization of the following: (1) The right of every person and all peoples to a healthy environment and to enhanced international cooperation that responds effectively to the needs for assistance of national efforts to adapt to climate change. 
international law debates are still being held on the status of the man's right to environment, while the procedural rights to environmental information, participation in environmental decision-making and access to justice on environmental matters have been progressively recognized.

In particular, the right to information was sanctioned by Principle 10 of the Rio Declaration, according to which, at national level, each individual shall have appropriate access to information concerning the environment that is held by public authorities. In addition, Principle 18 of the Declaration affirms that 'States shall immediately notify other States of any natural disasters or other emergencies that are likely to produce sudden harmful effects on the environment of those States. Every effort shall be made by the international community to help States so afflicted' ${ }^{72}$

In this perspective, that of the affirmation in general international law of the right to environmental information, the importance of the 1986 IAEA Conventions on Early Notification of a Nuclear Accident and on Assistance in the Case of a Nuclear Accident or Radiological Emergency has been underlined. Other treaties that gave a decisive contribute to the recognition of this right were the 1991 Espoo Convention on Environmental Impact Assessment in a Transboundary Context ${ }^{73}$ and especially the 2001 Aarhus Convention on the Right to Information, Participation in Decision-Making and Access to Justice in Environmental Matters (Aarhus Convention), ${ }^{74}$ which affirmed in the widest sense the environmental procedural rights of the public in the case of any activity which may have significant effects on the environment.

As noted, the reaction to the Chernobyl accident gave also a boost to the evolution of international treaty law in the nuclear energy sector. Amongst the most significant steps taken, there was the revision of the conventions on nuclear liability, which stemmed from the recognized need to increase the amounts of liability and to broaden the types of damage that were provided for in the previously existing legal regime. ${ }^{75}$

These conventions and various others adopted in the following years together constitute a new, complex legal framework within which power plants must be built and operated or dismissed today.

Despite all these improvements, the accident at the Fukushima Daiichi NPP in Japan in 2011 testifies how some fundamental questions raised by the Chernobyl accident remain open. Among these, that of international responsibility for transboundary environmental damage in general (customary) international law.

72 The Projet de Pacte international relatif au droit des êtres humains à l'environnement of the International Centre of Comparative Environmental Law declares that. 'Les Etats Parties s'engagent à ce que tous les droits de l'homme consacrés par le droit international soient garantis aux personnes susceptibles d'être affectées par des catastrophes naturelles ou industrielles. Elles ont droit en particulier à des informations préalables sur les risques encourus, sur les pertes antérieures ainsi qu'à un système d'alerte rapide et efficace' (Article 15 - Droit des personnes en cas de catastrophe).

73 The Application of the Espoo Convention on EIA in a Transboundary Context to Nuclear Energy - Related Activities, article based on a background note prepared by the NEA - Nuclear Energy Agency in 2015, 97 Nuclear Law Bulletin, OECD - NEA (2016) 63-69.

74 Morgera (2015) 138-47.

75 We share the opinion according to which the Chernobyl tragedy helped to:

(i) strengthen and broaden international co-operation in the case of a nuclear accident

(ii) ensure the adoption of international conventions in areas that had previously been regulated by soft law standards

(iii) bring international conventions on civil liability for nuclear damage up to date, see Lamm (2017) 44 . 
On this point, it seems useful to note that already in 1986 there was a widespread tendency to affirm in international law the principle of responsibility of the territorial State for transboundary environmental damages, remaining controversial whether this responsibility had to be considered as deriving from unlawful act, or also from a lawful act (liability).

However, States have always been reluctant to admit their responsibility for transboundary environmental damages and, in the case of the use of atomic energy, if they have sometimes compensated the victims, they have at the same time taken care to underline that this was not to comply and do not represent, a recognition of a legal obligation. ${ }^{76}$ The problem remains in fact, particularly acute in relation to the long-distance atmospheric pollution deriving from nuclear activities.

\section{FINAL REMARKS}

The analyzed activities aimed at addressing the consequences of the Chernobyl accident constitute a unique experience. ${ }^{77}$ Since 1986 , the UN organizations and programmes, the EU and the Development Cooperation of various countries, as well as NGOs and foundations, have launched and carried out more than two hundred different research and assistance projects in the fields of health, nuclear safety (including the construction of the Shelter), socio-psychological assistance, economic rehabilitation, environmental information and restoration, food quality control.

Since 1990, in Ukraine more than a thousand acts of various legal nature have been adopted, aimed at determining the legal status and safe management of the territories affected by the Chernobyl accident, ${ }^{78}$ as well as resolving issues of state social support for people affected by it. The radiation condition of the territories affected by radioactive contamination has improved and there has been a reduction in the levels of exposure of people living in the area. Notwithstanding this, nuclear contamination still is a priority environmental problem in Ukraine.

The activities of the international cooperation, the policies in the nuclear energy sector, as well as the Ukrainian legislation related to the consequences of the accident were since the very beginning inspired by the aim of restoring the environment and progressively by the guiding principle of sustainable development.

In this context, the prospect opened by the examined Presidential Decrees of 2018 and 2019 on the rehabilitation of the territories affected by radioactive contamination, is of exceptional interest. They contain, as noted, measures aimed at promoting scientific research, sound environmental management and development of sustainable tourism. Moreover, the effective establishment of a biosphere reserve and the idea of creating a transboundary biosphere reserve with Belarus, call for further reflection on the great potential in terms of territorial / land governance offered by cross-border protected areas.

76 'Se qualche volta hanno provveduto ad indennizzare le vittime ... hanno nel contempo avuto cura di sottolineare il carattere grazioso dell'indennizzo medesimo', Conforti (1987) 206.

77 According to Burns (2018) 7, in public consciousness, three major nuclear power accidents have dominated the debate over the safety of nuclear power operations: the 1979 Three Mile Island accident in the United States, the 1986 Chernobyl accident, and the multi-plant Fukushima Daiichi accident. And though each accident has had an impact, the Chernobyl accident has clearly been the most significant driver of change in the international legal regime.

78 The efforts to face specific problems like that of the management of forests under a massive radioactive contamination in the area must be mentioned, see Nepyivoda (2008) 235-50. 


\section{LITERATURE}

Andrian, Giorgio, Melen, Oya, 'Biosphere Reserve in Countries in Transition: The Evolution of the Concept of Biosphere Reserve in National Legislation of Ukraine', in Tamburelli, Gianfranco (ed.), Biodiversity Conservation and Protected Areas. The Italian and Ukrainian Legislation (Giuffrè Editore 2017) 245-70.

Gaetano Arangio-Ruiz, 'Some International Legal Problems of the Civil Uses of Nuclear Energy' (extract of the Recueil des Cours, Sijthoff A. W. 1962).

Balyuk, G. I., (Балюк, Г. I.), 'Правові засади державної екологічної політики України: сучасні проблеми' (Legal Foundations of State Environmental Policy of Ukraine: Current Issues) (2017) 3-4 Екологічне право 8-15.

Baranovskaya N. and Yukiko M. (Барановская Н., Юкико М.) 'Города и их жители после радиционной аварии (на примере Киева и Фукусимы)' (Cities and their Residents after Radiation Accident [Kyiv and Fukushima Cases]) (2017) 1 Місто: історія, культура, суспільство $67-84$.

Belyaninova, Yu. V. (Белянинова, Ю.В.) Комментарий к Закону Р Фот 15 мая 1991 г. № 1244-1 'O социальной защите граждан, подвергшихся воздействию радиации вследствие катастрофы на Чернобыльской АЭС (Commentary to the Law of the Russian Federation of May 15, 1991 no. 1244-1 'On the social protection of citizens exposed to radiation due to the Chernobyl disaster) (GARANT System 2014)<http://base.garant.ru/57623346/>accessed 15 October 2019.

Burns, Stephen G., 'The Impact of the Major NPP accidents on the International Legal Framework for Nuclear Power' (2018) 2 Nuclear Law Bulletin 7-69.

'Chernobyl: gli effetti dopo 30 anni', (2016)4-6 Almanacco della Scienza, CNR.

Clerici, Alessandro, 'Nucleare: La situazione europea tra investimenti, uscite e sviluppi, Orizzont Energia' $\quad(2018)<\mathrm{https}$ ://www.orizzontenergia.it/nucleare-la-situazione-europea-tra-investimentiuscite-e-sviluppi-2/>accessed 21 March, 2019.

Conforti, Benedetto, Diritto internazionale (3a ed. Napoli 1987).

Demichev, D. M. (Демичев, Д. М.), 'Организационно-правовые проблемы минимизации последствий чернобыльской катастрофы в рамках Союзного государства Беларусии России' (Organizational and Legal Problems of Minimizing the Consequences of the Chernobyl Disaster Within the Framework of the Union State of Belarus and Russia) (2012) Юридическая наука $67-74$.

Dolin, V.V, Orlov, O.О., (Долін, В. В., Орлов, О.О.) ‘Наукове обгрунтування на загальнозоологічний заказник «Чорнобильський» загальнодержавного значення.' (Scientific Substantiation on the All-Zoological Preserve 'Chernobyl' of National Significance) <http://pryroda.in.ua/kyiv-region/ zakaznyky/zahalnozoolohichnyy-zakaznyk-zahalnoderzhavnoho-znachennya-chornobylskyyspetsialnyy/> accessed 15 April 2019.

Gaja, G., 'Incidente a Chernobyl e Obbligo di Informazione' (1986) Rivista di Diritto Internazionale $826-29$.

Golovko, I. (Головко I.), 'Світ відмовляється від атомної енергетики: чому Україна на порозі катастрофи' (The World Refuses Nuclear Power: Why Ukraine is on the Verge of a Catastrophe) (2018) <https://www.khustnews.in.ua/novini/ukrayina/28713-svt-vdmovlyayetsya-vd-atomnoyienergetiki-chomu-ukrayina-na-poroz-katastrofi.html> accessed 10 May, 2019.

'International Nuclear Law in the Post-Chernobyl Period', Joint Report by the Organization for Economic Cooperation and Development - OECD Nuclear Energy Agency and the International Atomic Energy Agency (2006).

Lamm, Vanda, 'Reflection on the Development of International Nuclear Law'(2017) 99 Nuclear Law Bulletin, OECD - NEA 31-44.

Lysanets, O. S., (Лисанець О. C.), 'Правове регулювання використання та охорони техногенно забруднених земель' (Legal Regulation of the Use and Protection of Technogenically Contaminated Lands) (2017) 4 Юридичний науковий електронний журнал 61-64.

Klimchuk, O., Gubar, Е., (Климчук, О., Губар, О.) 'Українські АЕС в режимі продовженого терміну експлуатації - наскільки це безпечно?' (Ukrainian Nuclear Power Plants in the Mode 
of Extended Service Life - How Safe it is?) (2017) <https://www.dw.com/uk> accessed 2 February 2019.

Malysheva, N., 'Organizational and Legal Foundations for the Establishing and Functioning of the System of Territories and Objects of the Nature Reserve Fund of Ukraine' in Tamburelli, Gianfranco (ed), Legal Systems for the Management of Protected Areas in Italy and Ukraine. The Experiences of the Lazio and Kyiv Regions (2008) 207-18.

Malyuga, L.Yu. (Малюга, Л. Ю.), 'Правові проблеми надання соціальних послуг громадянам, які постраждали внаслідок Чорнобильської катастрофи' (Legal Problems of Providing Social Services to Citizens Affected by the Chornobyl Disaster) (2013) 4 Університетські наукові записки 264-70, <http://nbuv.gov.ua/UJRN/Unzap_2013_4_34> accessed 26 October 2019.

Mann, Thomas, 'The Legal Status of Nuclear Power in Germany' (2014) 94 Nuclear Law Bulletin OECD - NEA 43-75.

Mohit, Abraham, 'Nuclear Liability: A Key Component of the Public Policy Decision to Deploy Nuclear Energy in Southeast Asia' (2014) American Academy of Arts and Science Research Paper 1-48 <https://www.amacad.org/sites/default/files/publication/downloads/nuclearLiability. pdf $>$ acceessed 15 April 2019.

Morgera, Elisa, 'An Update of the Aarhus Convention and Its Continued Global Relevance' (2015) 2 Review of European Community and International Environmental Law 138-47.

Nasvit, O. I. (Насвіт, О.І.), Політика України щодо подолання наслідків Чорнобильської катастрофи: історія формування, проблеми реалізації та перспективи підвищення іiі ефективності: аналітична доповідь' (Ukraine's Policy on Overcoming the Consequences of the Chernobyl Catastrophe: History of Formation, Problems of Implementation and Prospects for Improving Its Efficiency: An Analytical Report) (Kyiv NISD 2016) <http://old2.niss.gov.ua/ content/articles/files/Chornobul-59c84.pdf> accessed 25 October 2019.

Nepyivoda, V., 'Law and Practice for Chernobyl Ecosystems: Integrating Conservation with Radio-Nuclides Stabilisation' in Tamburelli, Gianfranco (ed), Legal Systems for the Management of Protected Areas in Italy and Ukraine. The Experiences of the Lazio and Kyiv Regions (2008) $235-50$.

Ratushnyi, S. М. (Ратушний, С. М.), 'Міжнародна технічна допомога в подоланні наслідків Чорнобильської аварії: правові аспекти (International Technical Assistance in Overcoming the Consequences of the Chornobyl Accident: Legal Aspects) (2010) 10 Правове регулювання економіки 299-312.

Report on Implementation of the Association Agreement between Ukraine and the EU 2018 (Government Office for Coordination of European and Euro-Atlantic Integration and Vice Prime Minister's Office for European and Euro-Atlantic Integration Kyiv 2019).

Sangermano, Monia, 'Accadde oggi: nel 1986 il disastro nucleare di Chernobyl, che uccide ancora dopo 31 anni' <http://www.meteoweb.eu/foto/accadde-oggi-nel-1986-disastro-nucleare-chernobyluccide-ancora-31-anni-gallery/id/891921/\#1> accessed 27 April 2017.

Shchoka, Iryna, 'Chernobyl is to Become a UNESCO Biosphere Reserve and a Wilderness' $<$ https:// wilderness-society.org/chornobyl-is-to-become-a-unesco-biosphere-reserve-and-a-wilderness $>$ accessed 10 August 2016.

Tamburelli, Gianfranco, 'UNESCO - Global Protected Area Programmes - An Overview' (2012) April, Environmental Policy and Law, 96-101.

Tamburelli, Gianfranco, 'International Cooperation for the Protection of the Environment: Real or Supposed Innovations?' (2016) 6 Gazzetta Ambiente, also available at the website of the WCEL - World Commission on Environmental Law of the IUCN - World Conservation Union $<$ https:// www.iucn.org/sites/dev/files/international_cooperation_tamburelli.pdfhttps://www.iucn.org/sites/ dev/files/international_cooperation_tamburelli.pdf $>$.

Tykhyi, Volodymyr, 'Chernobyl Sufferers in Ukraine and Their Social Problems: Short Outline' in Imanaka, T. (ed.), Research Activities About the Radiological Consequences of the Chernobyl NPS Accident and Social Activities to Assist the Sufferers by the Accident (Japan 1998) $235-45$. 
UN Secretary-General, 'Optimizing the International Effort to Study, Mitigate and Minimize the Consequences of the Chernobyl Disaster', Report, A/71/411, 28 September 2016.

World Commission on Environment and Development (WCED), 'Environmental Protection and Sustainable Development: Legal Principles and Recommendations' (adopted by the Expert Group on Environmental Law, June 1986), London, 1987.

Zgersky, Milan, 'Legal Regime of the Chernobyl Problems in the USSR, Belarus, Russia and

Ukraine', in Imanaka, T. (ed.), Research Activities About the Radiological Consequences of the Chernobyl NPS Accident and Social Activities to Assist the Sufferers by the Accident (Japan 1998) 266-70. 